\title{
David Oliver: Can the extra funds for the NHS really transform care?
}

\author{
David Oliver consultant in geriatrics and acute general medicine
}

Berkshire

The now departed health secretary, Jeremy Hunt, and NHS England's chief executive, Simon Stevens, deserve praise for securing the promised $3.4 \%$ annual increase in funding for the NHS for five years from 2019-20. ${ }^{1}$ I see this as a victory, considering the backdrop of sustained cuts in other government departments, the reluctance to raise taxes, and the potential impact of Brexit on the economy. ${ }^{23}$ But it's still less than the 4\% annual increase that the King's Fund, Nuffield Trust, Health Foundation, and Institute for Fiscal Studies have agreed that the NHS needs if it is to maintain even current service levels, let alone compensate for several years of funding increases well below historical averages. ${ }^{4}$

In return for the additional funding, the government will want to see improved performance and value for money, as well as health service reforms. Stevens is set to announce a long term plan for the NHS this autumn. He has already signalled likely priorities such as improved cancer outcomes, mental health, children's services with a focus on prevention and inequalities, and a renewed focus on stroke and cardiovascular disease. ${ }^{5}$

There seems to be a broad consensus among the health policy community, professional bodies, and health and social care leadership that we need to increase social and community care provision and invest more in prevention, wellbeing, and the wider determinants of population health. ${ }^{6}$

The difficulty over the next few years, as in the previous decade, is that serious transformation of care models will be hard to deliver when the service is under such pressure. Acute beds are already crammed full, performance is slipping on a range of indicators across all health sectors, ${ }^{78}$ and we have a workforce crisis. ${ }^{9}$ We have systematically reduced funding to public health and social care since $2010^{10}$ and have yet to see the government's green paper proposals on social care funding. The $3.4 \%$ uplift doesn't apply to public health services provided by local government.

In the NHS, immediate political and operational imperatives and crises generally trump the needs of the future, as we saw last year when funding earmarked for mental health and primary care was held back to deal with deficits. ${ }^{11}$
Already, NHS Providers has calculated, ${ }^{12}$ we have a deficit of around $£ 4$ bn in the acute hospital sector to tackle, an estimated minimum expenditure on buildings and equipment to fund, ${ }^{13}$ and a relaxation of the $1 \%$ cap on NHS annual pay increases, which the Treasury estimates will cost another $£ 4$.2bn a year even without planned expansion in workforce numbers. ${ }^{14}$

In the NHS, immediate political and operational imperatives generally trump the needs of the future

I'd say it's doubtful that we can realise efficiencies at the scale and pace that would make the additional $£ 21$ bn of NHS funding go that much further, despite assumptions in the Carter review that we could save $£ 5$ bn a year ${ }^{15}$ or last year's assertion by NHS Improvement's Tim Briggs that the NHS deserved no more money until it became more efficient. ${ }^{16}$

For all of this, I don't see any further funding uplifts heading the NHS's way-so, while continuing to highlight underfunding, we as clinicians will also have to engage as best we can in helping to sustain, improve, and transform services.

Competing interests: See www.bmj.com/about-bmj/freelance-contributors/davidoliver.

Provenance and peer review: Commissioned; not externally peer reviewed.

Gershlick B. NHS funding settlement: "a change of gear" for the NHS? Health Foundation. 26 June 2018. https://www.health.org.uk/blog/nhs-funding-settlement-change-gear-nhs.

2 Charlesworth A. Anita Charlesworth: Do we want a sustainable NHS enough to agree to higher taxes? BMJ Opinion 24 July 2018. https://blogs.bmj.com/bmj/2018/07/24/anitacharlesworth-do-we-want-a-sustainable-nhs-enough-to-agree-to-higher-taxes/.

3 Chu B. "Brexit dividend" for health service a myth, government's official spending watchdog confirms. Independent 17 July 2018. https://www.independent.co.uk/news/business/news/ brexit-dividend-nhs-obr-fiscal-sustainability-report-a8450731.html.

4 Stoye G. The NHS at 70: Does the NHS need more money and how could we pay for it? King's Fund. 26 June 2018. https://www.kingsfund.org.uk/publications/nhs-70-does-thenhs-need-more-money.

5 West D. Exclusive: Stevens sets out 10 year plan priorities. Health Serv J 2018. https:// www.hsj.co.uk/commissioning/exclusive-stevens-sets-out-10-year-plan-priorities/7022947. article.

6 Ham C, Murray R. The NHS 10-year plan: how should the extra funding be spent? King's Fund. 12 July 2018. https://www.kingsfund.org.uk/publications/nhs-10-year-plan.

7 King's Fund. The number of hospital beds. 29 Sept 2017. https://www.kingsfund.org.uk/ projects/nhs-in-a-nutshell/hospital-beds.

8 Anandaciva S, Jabbal J, Maguire D, Ward D. How is the NHS performing? June 2018 quarterly monitoring report. King's Fund 10 July 2018. https://www.kingsfund.org.uk/ publications/how-nhs-performing-june-2018. 
9 Siddique H. NHS England has one in 11 posts unfilled. Guardian 21 Feb 2018. https:// www.theguardian.com/society/2018/feb/21/nhs-england-has-one-in-11-posts-unfilled.

10 Umali G, Case R, Miller B. Social care reform at a fork in the road, says new report. King's Fund. 16 May 2018. https://www.kingsfund.org.uk/press/press-releases/social-care-reformfork-road-says-new-report.

11 Thomas R. Primary care underspend helps counter trust deficits. Health Serv J 2017. https://www.hsj.co.uk/primary-care/primary-care-underspend-helps-counter-trust-deficits/ 7020337.article.

12 NHS Providers. The state of the NHS provider sector: funding and finances. https:// nhsproviders.org/state-of-the-provider-sector-07-17/funding-and-finances.

13 Naylor R. NHS property and estates: why the estate matters for patients. March 2017. https://assets.publishing.service.gov.uk/government/uploads/system/uploads/attachment_ data/file/607725/Naylor_review.pdf.
14 Triggle N. NHS pay: unions agree deal for 1.3 million staff. BBC News 21 March 2018. https://www.bbc.co.uk/news/health-43481341.

15 Evans TW. The Carter report: reducing unwarranted variation in operational performance \& productivity in hospitals in England. Department of Health. http://nhsproviders.org/media/ 2078/lord-carter-review-tim-evans-fin-com-21-june-2016.pdf.

16 NHS doesn't deserve more money until it "puts its house in order" to stop waste, says healthcare inquiry chair. Independent 4 Aug 2017. https://www.independent.co.uk/news/ uk/home-news/nhs-money-funding-wasting-standards-care-improve-healthcare-inquirytim-briggs-professor-quality-a7876326.html.

Published by the BMJ Publishing Group Limited. For permission to use (where not already granted under a licence) please go to http://group.bmj.com/group/rights-licensing/ permissions 